the pupil should find a foundation that he can build upon even in the highest classes. This applies not only to the grammar, but also to the reading of authors : in discussing the meanings of words, the constructions, even the subject-matter, there is constant reference to the first Reader.

There is always a blackboard on the wall behind the class, at which two pupils can write at the same time; especially during the time when the home-work is gone through, ${ }^{1}$ there are always two pupils busy writing the translation of sentences; as soon as it is written out, the class turns round and corrects what is written. Thus each day the master has a visible proof of what the class can or cannot do; many a mistake is scotched here before it can get into the pupils' work.

The same system is used in Greek : for

${ }^{1}$ Sometimes they translate sentences from a paper put into their hands; sometimes they write down sentences that have previously been translated orally by another pupil. These boys are of course removed from the class-work for that hour. each new rule the examples found in the text are then seen collected, that the rule may be deduced from them.

Question and answer on the text in Greek and Latin is not discontinued when the reading of continuous pieces begins. The ancient languages must not exist for the pupil only on paper; but of course the ultimate aim is to interpret the text, which must never be sacrificed by the use of a foreign language.

The question has often been put, on what principle we interpret the authors, whether grammar or literary appreciation come first. I can only reply, scholarship. The exact understanding of the foreign language comes first, the vivifying of the text thus understood comes second: the second is impossible without the first, the first worthless without the second. Of course this is nothing peculiar to the Goethe-Gymnasium; every one will do the same who has himself learnt scholarship in the modern sense.

E. BRUhN.

\title{
FURTHER NOTES ON THE FOURTH ECLOGUE.
}

IN an essay contributed by me to a volume entitled 'Virgil's Messianic Eclogue,' which appeared last autumn, I endeavoured to show that the phrase Cumaeum carmen was most naturally understood of one of those forged Sibylline prophecies, which were rife in the first century B.C., and of which we have specimens preserved to us in the very miscellaneous collection known to us as the Third Book of the existing Sibyllines. The greater part of this book is generally assigned by the later editors, following Alexandre, ${ }^{1}$ to the year 170 B.c. or thereabouts, on the ground that we have thrice over (in $11.191-193,318,608-615$ ) a reference to the seventh king of the Macedonian dynasty,

\footnotetext{
${ }^{1}$ For the benefit of those who may not be acquainted with Alexandre's excellent work on the Sibyllines, it may be worth while to quote the words in which the latest German editor expresses his high appreciation of the French scholar (p. xiv): "Wer nicht an Alexandre anknüpft, nicht in seinem Bahnen weiter wandelt, dürfte itber die Sibyllina kein Urteil fällen.'
}

who would be either Ptolemy Philometor, whose reign began in 181 , or his brother Ptolemy Euergetes, nicknamed Physcon, who was made king in $\mathbf{I} \mathbf{1}$, when Philometor was defeated and carried away captive by Antiochus Epiphanes. If we include Alexander himself as the head of the line of seven kings, Philometor would be the seventh, if we exclude him, Physcon. Antiochus repeated his invasions in four successive years, which are alluded to in ll. 6ri foll., where we read of a mighty king coming from Asia, who should overthrow Egypt and carry away its treasures in ships. Alexandre, following the rule that the date of a supposed prophecy may be fixed at the point where historical fact passes into vague imagination, concludes that it must have been written during the stress of the Syrian invasion and previously to the death of Antiochus in 164, because it is stated that the invasion is immediately to be followed by the conversion of the idolatrous nations to Judaism, which 
has nothing corresponding to it in history. Another reason for supposing that the main part of the book was written about this time is, that in it Rome is described as a growing power, notorious for its extortions and oppressions in Macedonia and Greece (ll. I $90 \mathrm{f}$., $5^{20}$ f.), for which she will be punished during the reign of the seventh ruler of Egypt. On the other hand, in the later portion of the oracle (ll. 295-489), Rome is at the height of her power, but destined shortly to suffer divine vengeance for destroying the temple at Jerusalem. I do not find any distinct trace of Christianity in either the older or the newer portions. Idolatry and immorality are the charges brought against the heathen, and their conversion is shown in their going up to the temple to offer hecatombs of rams and bulls at the altar of the one true God. There is no reference either to Christian doctrine or to the story of the Gospels, such as we find in some of the other Sibyllines, e.g. the baptism of John, the descent of the dove, the doctrine of the Trinity in vii. 65 foll. On the other hand there are lines which have no more to do with Jewish or Christian thought than the oracular sayings quoted in

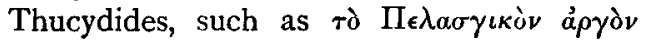
a $\mu \epsilon \iota v o v$, which are probably the work of a pagan sibyl written considerably before the rest.

Following the hints dropped by Mr. Warde Fowler, I pointed in my essay to the close connexion between Egypt and Judaea on the one side, the two main sources of Messianic ideas, and to Rome on the other side, during the latter half of the century which preceded the battle of Actium; and the consequent probability that these ideas must have found their way to the imperial city before 40 B.C. Perhaps I may have failed to lay sufficient stress on the extraordinary-I may call it the portentous-development of Messianic ideas throughout the East at this time. 'The Kingdom of Heaven is at hand' is the keynote of the synoptic Gospels. That a great deliverer, a prince of peace, was about to appear, was accepted by the vast majority of Jews, both in their native land, and in the lands of the Diaspora. The only questions on which doubt was entertained were, Who is the deliverer? What is his sign? When, and where, is he to appear? The evidence of contemporary Pseudepigrapha and of Josephus is quite in accordance with that of the N.T. upon this point. Even the most Philistine of Roman soldiers could not help acknowledging the might of this hope, when they had to face the furious onslaughts of fanatics such as Hezekiah or Judas of Galilee. The longing for the promised deliverer was intensified by the wide-spread misery caused among the Jews by the competing claims of individuals and of nations, of Hyrcanus and Aristobulus, Herod and Antigonus, Caesar and Pompey, Antony and Octavian, Parthia and Rome. And Parthia now represented the third of the partners mentioned in Isaiah xix. 24, "In that day shall Israel be the third with Egypt and with Assyria, a blessing in the midst of the earth.' The Babylonian Diaspora was one of the most important centres of Judaism. That it fully shared in the hope of the Messiah appears from the story of the Magi, whether we regard it as legend or history, and it is confirmed at a later date by the' statements of Josephus, Tacitus and Suetonius, as to the wide-spread expectation of a world-ruler to come forth from the East, which was believed to be fulfilled in the accession of Vespasian.

If I am not mistaken, Virgil alludes to similar Messianic prophecies, proceeding from Babylon and Alexandria, in Aen. vi. 799, where, speaking of Augustus, he says :

\footnotetext{
Huius in adventum iam nunc et Caspia regna

Responsis horrent divum et Macotia tellus,

Et septemgemini turbant trepida ostia Nili ;
}

implying that Augustus is the heir of the Sibylline prophecies of a golden age and of that reign of peace, of which he had spoken just before;

Hic vir, hic est tibi quem promitti saepius audis, Augustus Caesar, Divi genus, aurea condet Saecula qui rursus Latio, regnata per arva Saturno quondam.

In my essay I quoted passages from the third book of the Sibylline oracles describing, almost in the very words of Virgil and of Isaiah, the golden age to come. There are other passages which might well be understood of Augustus by his adherents, such as 
the picture of a heaven-sent king who should put an end to war (1. 652):

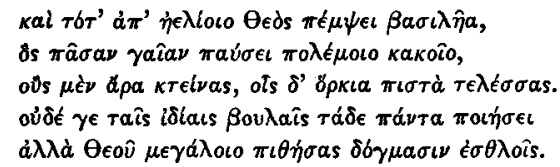

Compare also 707 foll. and 754 foll. Another characteristic of the reign of Augustus is the establishment of safe communications by sea and land, described in 775 foll., which is itself borrowed from Isaiah's ideal description of the return from Babylon.

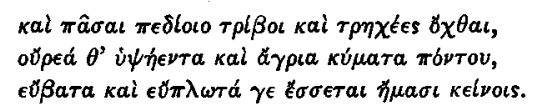

In the same book almost every part of the known world comes in for its share of alternate blessing and cursing, e.g. Maeotis in $33^{8}$, $\kappa \alpha i$

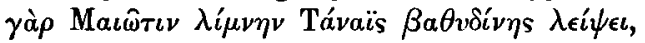
Gog and Magog in 512 ; but above all Babylon (which the Sibyl claims as her fatherland), Egypt, Judaea, Greece and Rome are taken as the theme of her predictions.

It is worthy of note that even the partisans of the alien Herod, the great foe of the Asmonean dynasty, endeavoured to support their leader's claims by appeals to the Messianic hope. Thus Josephus tells us (Antiq. xv. 10. 5) that the reason of the special favour which Herod showed towards the Essenes was that a prophet of theirs, named Menahem, had announced to him, when he was a schoolboy, that he would one day be king of the Jews. And we learn from Epiphanius (Haer. xx.) that Jacob's prophecy with regard to Judah, contained in Gen. xlix. Io, 'the sceptre shall not depart from Judah until Shiloh come' (for which

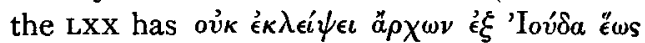

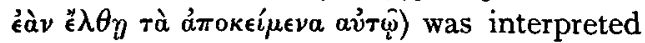

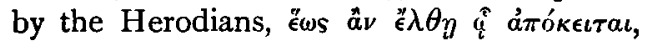
'till he shall come for whom it is reserved,' viz. Herod. ${ }^{1}$ So in the doubtful appendix to Tertullian's De Praescriptionibus we read

1 I see no reason for doubting this statement of Epiphanius. He had no motive for imputing such an interpretation to the Herodians, and, however lightly we may esteem his judgment and reasoning powers, we are certainly indebted to him for much valuable information.
'Herodiani Christum Herodem esse dixerunt.'

We come now to an important connexion between Herod and a certain Pollio or Polio or Ptollio, whom Josephus distinguishes as o Sapuraíos (Ant. xv. I. 1, 10. 4) and describes as a man of great weight in the Sanhedrim. ${ }^{1}$ He and his pupil Samias were in peculiar favour with Herod, the former for his prudent advice when Herod was summoned before the Council to answer for his slaughter of the Galileans in B.c. 47 , the latter for his courageous outspokenness (Ant. xiv. 9. 4). Ten years afterwards both joined in urging their countrymen to open the gates of Jerusalem to the besieging Herod. This Pollio is known in the rabbinical writings as Abtalion, ${ }^{2}$ the vicepresident of the Sanhedrim, who is stated to have been of foreign birth. If this was so, it would be an additional confirmation of Mr. Garrod's suggestion that he may have been an actual kinsman of Asinius Pollio, and have become 'a proselyte of righteousness.' In any case the choice of the name Pollio implies a certain connexion between the Pharisee Abtalion and the Roman Pollio.

And now let us see what Josephus has to tell us of this latter. After the rebuilding of the city of Sebaste (i.e. Samaria) we are told (Ant. xv. Io. I) that Herod determined to send his two sons by Mariamne; Alexander and Aristobulus, to Rome in order to introduce them to Augustus ( $\sigma v v \tau \in v \xi \xi^{\prime} \mu \epsilon v o v s$ Kaírapt) and also for their education ( $A n t$. xvi. I. 2). ${ }^{3}$ Perhaps, too, it may have been thought expedient to remove them from the miasma of a palace reeking with kindred slaughter to the healthier atmosphere of

\footnotetext{
1 Attention was first called to the connexion between Herod and the two Pollios, as bearing on the interpretation of the Fourth Eclogue, by Mr. H. W. Garrod in his very interesting note in the Classical Review for Feb. 1905, p. $37 \mathrm{f}$, which I grieve to have overlooked in writing my own essay.

${ }^{2}$ See Jewish Encyclopaedia under this name.

${ }^{3}$ This was a common custom with the princes of the Herodian house, as in the case of Herod's other sons, Philip, Archelaus, and Antipas (Ant. xvii. I. 3), of Herod Agrippa I. with his two brothers Aristobulus and Herod of Chalcis, grandsons, and Herod Agrippa II. great grandson, of Herod the Great.
} 
Rome. It was arranged that they should live in the house of Asinius Pollio, who was

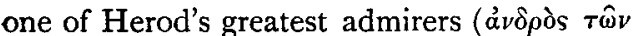

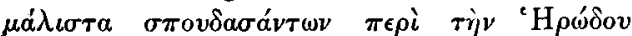

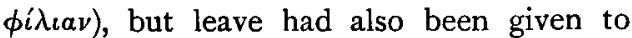
them to share the hospitality of Augustus

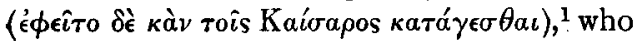
received them with the greatest kindness. The fact that the boys were put under the guardianship of Pollio is a sufficient proof of the friendship existing between Herod and Pollio, and also of the latter's fitness to see that they were brought up as Jews, for Herod showed on many occasions his anxiety not to offend Jewish feeling. But Josephus (Ant. xiv. 14. 5) tells us of an earlier meeting between Herod and Pollio in the year 40 B.c. in which Virgil too met Pollio and addressed his famous Eclogue to him. Herod had been just driven out of Judea by Antigonus and the Parthians. His patron, Hyrcanus, the nominal ruler of the country, had been carried captive into Parthia, where he was warmly welcomed by the Jews of Babylon. In the autumn of that year Herod escaped to Alexandria and thence to Rome, where he was well received by Antony, the friend of his father, Antipater, and by him commended to Octavian. In a few days he was declared king of the Jews by a vote of the Senate, and ascended to the Capitol between the two triumvirs, preceded by the consuls $\mathrm{Cn}$. Domitius Calvinus and C. Asinius Pollio. At a later period Josephus tells us (Ant. xv. Io. 3) that Augustus preferred him to all his other friends except Agrippa, and that Agrippa in like manner preferred him to all his friends with the exception of Augustus.

\footnotetext{
${ }^{1}$ The date of this mission to Rome is a little doubtful. Mr. Garrod puts it ' about the year 24 B.C. or possibly 27 B.c.' Schürer, Jewish People (Eng. tr. vol. i. p. 408) assigns it to 23 B.C. and has a note discussing the date of the building of Samaria in pp. $405 \mathrm{f}$. I think Schürer's date agrees better with the probable age of the children. The marriage of Mariamne took place in 37 B.C. and she was put to death in 29 B.c., when her two eldest sons would probably have passed their sixth birthday. They would thus have com. pleted their twelfth year (when a Jewish youth became 'son of the Torah,' corresponding to our coming of age) in 23 B.C., and be about the age of seventeen or eighteen at the time of their return home, after they had completed their education ( $A n t$. xvi. I. 2 ).
}

Mr. Garrod thinks it possible that there may have been a Jewish colouring in Pollio's own poems, and that this may have influenced Virgil in writing his fourth Eclogue. I learn from Mr. Warde Fowler that Mr. R. W. Raper has carried this view further, and sees signs of Jewish influence in $E c l$. iii. 86, 'Pollio et ipse facit nova carmina,' in connexion with the Hebraic cast of 1.88 , 'mella fluant illi, ferat et rubus asper amomum.' He thinks too that in Georg. iii. 10-13,

Primus ego in patriam mecum modo vita supersit, Aonio rediens deducam vertice Musas,

Primus Idumaeas referam tibi Mantua palmas,

the epithet 'Idumaeas' may not be merely conventional, but may indicate Virgil's intention of writing again in the Hebrew style. In the fourth Eclogue he thinks the Sibyl ends with 1.48 , and that Virgil himself breaks in with 'Aggredere $\mathrm{O}$ magnos.' 1

Pollio's relation to the Jews at once suggests a way in which Virgil may have made acquaintance, not only with some Sibylline paraphrase of Isaiah, but with the actual volume of the O.T. Scriptures. And that this was so is, I think, rendered probable by the close resemblance between certain lines of the fourth Eclogue, noticed in my Essay, and the language of Isaiah, where the Sibylline offers no parallel. Possibly we may find another proof in Georg. i. I 2 I foll.:

Pater ipse colendi
Haud facilem esse viam voluit.
Ante Iovem nulli subigebant rura coloni,
$* *$ ipsaque tellus
Omnia liberius nullo poscente ferebat.
Ille malum virus serpentihus addidit atris
Praedarique lupos voluit * * *
Mellaque decussit foliis ignemque removit,
$*$ * * * * * *
Ut varias usus meditando excuderet artes.

This passage is supposed to be borrowed from Hesiod's story of the act of Prometheus which called down the wrath of Jupiter upon men. And I am quite ready to believe that this suggested to Virgil his reference to the deprivation of fire. But it seems to me that the main features of this passage are more

\footnotetext{
${ }^{1}$ Since this was written Mr. Raper has stated his view more fully in the February number of the Classical Revieze.
} 
easily derived from the story of the Fall in Genesis, and the sentence passed on Adam, 'Cursed is the ground for thy sake; Thorns also and thistles shall it bear; In the sweat of thy brow shalt thou eat bread'; as well as from the curse by which the serpent became the enemy of man. Just as Virgil ascribes the origin of the arts to the severity of Jupiter, so we find the loss of Eden leading to various inventions; farming in both branches, introduced by Cain and Abel ( $G$. i. I $5 \circ$ foll.), working in iron and brass by Tubalcain $(G$. i. I43), hunting by Nimrod ( $G$. i. I 39 f.).

I conclude with a suggestion from Prof. Lewis Campbell on the difficult word 'incrementum,' which he understands of the future heightening and magnifying of the righteous rule of Jupiter, to be brought about by the impending birth. The word would thus have the force of 'development,' compared with the Indian avatar. Perhaps it may remove the objection some have to Munro's interpretation, if we remember that Virgil, like Ennius, - often speaks as a Euhemerist, as in Georg. ii. 536, where the 'Sceptrum Dictaei regis' is contrasted with the happier rule of Saturn. In any case the difficulty is not greater than in Georg. $i$. 24-42, where it seems to be open to Augustus to assume the sovereignty of earth or sea or Hades at his pleasure.

\section{JOSEPH B. Mayor.}

${ }^{1}$ Mr. Warde Fowler compares Liv. v. 54, where Camillus, arguing against the removal to Veii, praises Rome as 'regionum Italiae medium, ad incrementum urbis natum unice locum.'

\section{CAESAR'S BRIDGE OVER THE RHINE.}

\section{Caesar, De Bello Gallico, iv. r7-Ig.}

THE problems of Caesar's bridge over the Rhine have been the subject of interesting discussions, but do not appear to have been completely solved, and I trust that a reference to them may be again permitted in the pages of the Classical Revieze, as I would wish to hazard a new explanation of the connection of the uprights to the horizontal beam.

In order to fasten this horizontal loadcarrying beam to the piers at either end of it, fibulae or braces were employed, and their application is defined by the words, Quibus disclusis atque in contrariam partem revinctis. This phrase develops the meaning of Distinebantur of the previous sentence, and describes a member whose function was at once to thrust apart and to tie together. The combination of these properties of strut and tie is neglected in the suggestions of Heller, Kraner, Cohausen and Peskett. In Napoleon III.'s design diagonals are introduced; these stretch from a low point on each leg of the trestle to a high point on the leg at the other end and form a St. Andrew's cross. But while the contrivance is eminently sound as a matter of design it does not fit the words, and would have been exceedingly difficult of execution; because the diagonals would have been cumbrous in the extreme [say $38^{\prime} \times I^{\prime} \times I^{\prime}$, weight 1330 lbs.], and the lower end of each would have had to be fixed some distance below the surface of the water if they were given sufficient inclination to make them of any considerable service. In Stock's drawing similar diagonals are applied entirely above the water surface; this would require the main piers to be of unnecessarily unmanageable proportions [say $\left.40^{\prime} \times 1^{\prime} \frac{1^{\prime}}{} \times \mathrm{I}^{\prime} \mathrm{2}^{\prime}\right]$.

If the latter schemes are dismissed as impracticable, almost more certainly will the mere pins of the other commentators fail of acceptance owing to their inefficiency.

For, when an erection on such a scale is made of timbers, the relative positions of the main members [viz. : the horizontal and the uprights] would be ill maintained in the presence of large disturbing forces by simple bolts at their crossing; there would be required supplementary members to subtend the crossing angle and preserve it against distortion. Such I believe the fibulae to have been. If this supposition is correct the horizontal beam was continued beyond 